\title{
Relationships between motivation, cognitive styles and perception of teaching practices for creativity
}

\author{
Relações entre motivação, estilos cognitivos \\ e percepção de práticas pedagógicas \\ promotoras de criatividade
}

\author{
Eunice Maria Lima Soriano de ALENCAR \\ Denise de Souza FLEITH ${ }^{1}$
}

\begin{abstract}
This study investigates differences between Pedagogy and Teachers' Certificate in Mathematics undergraduates, males and females, from public and private institutions with respect to motivational orientations, cognitive styles and perception of pedagogical practices for creativity implemented by their teachers, as well as relationships between these variables. Three hundred and sixty-five students answered scales regarding motivation to learn, cognitive styles, and teaching practices for creativity. Intrinsic motivation predominated in the private university students and extrinsic motivation in the public university students. The data revealed differences between courses, gender and type of university concerning cognitive styles. Private university and pedagogy students had a more positive perception of professors' teaching practices that promote creativity. Positive relationships were observed between the factors of the instrument of pedagogical practices for creativity, intrinsic motivation and nonconformist transformer style, and between the various cognitive styles and intrinsic and extrinsic motivational orientation.
\end{abstract}

Keywords: Cognitive style; Creativity; Motivation; Teaching practice.

\section{Resumo}

Este estudo investiga diferenças entre estudantes de Pedagogia e de Licenciatura em Matemática, dos gêneros masculino e feminino, de instituições públicas e particulares quanto a orientações motivacionais, estilos cognitivos e percepção de práticas pedagógicas promotoras da criatividade utilizadas por seus professores, bem como relações entre essas variáveis. Trezentos e sessenta e cinco estudantes responderam a escalas referentes à motivação para aprender, estilos cognitivos e práticas docentes para a criatividade. Motivação intrínseca predominou nos estudantes da universidade particular e a extrínseca nos da universidade pública. Os dados revelaram diferenças entre cursos, gênero e tipo de universidade nos estilos cognitivos. Estudantes de universidade particular e de Pedagogia perceberam de forma mais

W

1 Universidade de Brasília, Instituto de Psicologia, Departamento de Psicologia Escolar e do Desenvolvimento. Campus Universitário Darci Ribeiro, Instituto Central de Ciências Sul, Prédio Minhocão, 70910-900, Brasília, DF, Brasil. Correspondência para/Correspondence to: E.M.L.S. ALENCAR. E-mail: <eunices.alencar@gmail.com>.

Support: Conselho Nacional de Desenvolvimento Científico e Tecnológico (Process no 300581/2008-4). 
positiva práticas pedagógicas promotoras da criatividade utilizadas por seus professores. Observaram-se relações positivas entre os fatores do instrumento de práticas docentes para a criatividade, motivação intrínseca e estilo inconformista transformador e entre os diversos estilos cognitivos e orientação motivacional intrínseca e extrínseca.

Palavras-chave: Estilos cognitivos; Criatividade; Motivação; Práticas pedagógicas.

The demands of the contemporary scenario marked by high competitiveness, complexity and rapid pace of change require from the individual more than knowledge, but also initiative and creativity. This is one of the reasons why educational institutions, particularly in the higher education scenario, must not be reduced to transmitting information, techniques and values, but rather develop students' flexibility, openness to new ideas, as well as their ability to adapt to new contexts and solve problems in an original way (Alencar \& Fleith, 2004a; Cropley, 2005; Rubenstein, McCoach, \& Siegle, 2013; Treffinger, Schoonover, \& Selby, 2013; Wechsler \& Nakano, 2011).

Although acknowledging the benefits of creativity both for the individuals and their personal development and society, fostering creativity has not been a priority at the different levels of education, commonly being repressed at school (Amaral \& Martínez, 2009; McCluskey, 2013; Renzulli, 2005). There is empirical evidence pointing out that the creativity of individuals declines over the years of formal education. Furthermore, various authors have highlighted the scarce opportunities and/or lack of incentive for creativity in the school context (Alencar \& Fleith, 2009; Csikszentmihalyi, 2006; Hosseini, 2011; Jackson, Oliver, Shaw, \& Wisdom, 2006; Lemons, 2005; Morgan \& Foster, 1999; Sternberg \& Lubart, 1995; Wechsler, 1998, 2002).

In recent decades, one of our main interests has been the investigation of several aspects related to creativity in higher education. While we recognize the importance of providing opportunities for creativity to flourish since the first years of education and the need for research on creativity in preschool and primary education, we, as well as Nakano and Wechsler (2007), notice that the vast majority of creativity studies in educational setting has been conducted with elementary school teachers and students. In spite of the increasing number of studies and publications about creativity in higher education, the literature reveals scarcity of investigations about the relationships between creativity and other variables such as motivation, self-efficacy and cognitive styles.

The role of motivational factors in creative expression has been widely discussed in the literature on creativity. In theoretical models that conceptualize creativity as a complex system resulting from the interaction between individual characteristics and environmental factors, one of the essential elements for the occurrence of creativity is motivation. In the Investment Theory of Creativity proposed by Sternberg (2006, 2012; Sternberg \& Lubart, 1995), for example, the author considers creative behavior as a result of the convergence of distinguished interrelated factors, one being motivation. Csikszentmihalyi (1994, 1999) also draws attention to motivation in his systems model to explain creativity. In addition to recognizing the greater likelihood of creative contributions in a social environment that provides resources, recognition and opportunity, the author highlights the complex interaction between the individual and the environment, considering intrinsic motivation as one of the most noticeable characteristics of creative individuals. Similarly, Amabile (1996; Amabile \& Mueller, 2008), who proposed the Componential Theory of Creativity, states that motivation, especially intrinsic motivation, is a key predictor for creativity. The relationship between intrinsic and extrinsic motivation and creativity was reviewed by Fleith and Alencar (2010). These authors collected empirical evidence and biographical reports that suggest a high level of motivation in creative work, circumstances in which extrinsic motivation can boost the creative process, and the types of extrinsic motivation that can coexist with intrinsic motivation in creative persons.

A frequently discussed topic in the literature on creativity has been the impact of teaching practices on creativity and motivation. Many scholars, 
such as Alencar and Fleith (2009), Cropley (2005), Fleith and Alencar (2010), Martínez (2002), Otaviano, Alencar, and Fukuda (2012), and Wechsler (2002), have consistently pointed out the beneficial effects of didactic procedures that emphasize creativity in student's motivation. Moreover, several authors, such as Lubart (2007), Treffinger (2003) and Wechsler (2006), have drawn attention to the importance of identifying not only the level of creativity in individuals, but also people's own personal preference for using their creativity, considering certain cognitive styles to be more compatible with creative thinking. Cognitive styles can be "understood as individual differences in cognitive organization, seen as mediators between ability and personality" (Nakano \& Siqueira, 2011, p.237). According to Sternberg (as cited in Kirschenbaum \& Armstrong, 1999), the assessment of style is an important step in programming an educational environment that is most likely to improve students' performance. Wechsler (2006) recognizes the importance of cognitive styles for creativity and emphasizes that "the assessment of thinking and creative styles allows one to know the creative potential of individuals for producing and excelling in many different areas" (p.i.). Different researchers interested in creativity have investigated cognitive styles. For example, in a study in which individual factors and environmental predictors of students' creativity were examined, Niu (2007) found that cognitive styles, along with other variables such as personality and motivation, significantly predicted the students' creativity. Phelan and Young (2003) also examined the relationship between cognitive styles, creative confidence and creative leadership in graduate students. The results indicated a relationship between innovative cognitive style and creative confidence.

Although motivational orientation and cognitive styles are constructs that have received increasing attention from researchers on creativity (Feist, 2010; Nakano, 2010; Nakano, Santos, Zavariz, \& Wechsler, 2010), there are few studies on the interrelationships between these variables, as well as investigations regarding their relationship to students' perception of their professors' teaching strategies that promote creativity. Among other benefits, the knowledge of these relationships can be used to help professors implement pedagogical practices in their classroom that ensure higher levels of motivation, particularly intrinsic motivation, as well as promote educational strategies that contribute to the development of students' creativity. These aspects were investigated in the present study with the purpose of examining: (a) possible differences between Pedagogy and Teachers' Certificate in Mathematics undergraduates, males and females, from public and private institutions with respect to motivational orientations, cognitive styles and perception of pedagogical practices for creativity implemented by their teachers; and (b) the relationship between the latter three variables.

\section{Method}

\section{Participants}

Three hundred and sixty-five students, 125 (34.2\%) men and 240 women (65.8\%) with a mean age of 24.41 (Standard Deviation - SD =6.36), participated in the study. Two hundred and five students $(56.2 \%)$ were enrolled in Pedagogy and 160 (43.8\%) in Teachers' Certificate in Mathematics course. Among the students from the School of Education, $24(11.7 \%)$ were men and the others ( $n=181 ; 88.3 \%$ ) were women. On the other hand, $101(63.1 \%)$ students from the Teachers' Certificate in Mathematics course were men and 59 (36.9\%) were women. One hundred and eighty-eight $(51.5 \%)$ were from a public university and 177 (48.4\%) from a private university. The distribution of participants per term ranged from the $1^{\text {st }}$ to $11^{\text {th }}$ term, with a predominance of college students in the $5^{\text {th }}(19.7 \%)$ and $3^{\text {rd }}$ terms $(16.2 \%)$. A convenience sample was used due to the difficulty of selecting students randomly.

\section{Instruments}

Motivation: The Learning Motivation Assessment Scale for University Students (Boruchovitch, 
2008a) consists of 32 items, 16 related to intrinsic motivation and 16 to extrinsic motivation. The items are answered on a 4-point scale ranging from strongly agree to strongly disagree. Examples of scale items that assess intrinsic motivation are as follows: I study because I like to acquire new knowledge; I like to study challenging issues. Some items assessing extrinsic motivation were: I am obliged to study; I only study because I want to get high grades. The scale was first validated using a sample of 101 college students. Internal consistency values were calculated using Cronbach's alpha coefficient. The alpha reliability coefficient for Factor 1 (Intrinsic Motivation) was 0.84, for Factor 2 (Extrinsic Motivation) was 0.76 , and for the general scale was 0.86 .

Cognitive Styles: The Scale for Thinking and Creative Styles (Wechsler, 2006) assesses five factors, the first three being considered the main factors and the last two, secondary factors: (a) Cautious/Reflective with 32 items (e.g., Novelty doesn't appeal to me); (b) Nonconformist/Transformer with 32 items (e.g., I like new ideas); (c) Logical/ Objective with 11 items (e.g., I prefer using rules and methods to do my job); (d) Emotional/Intuitive with 7 items (e.g., I make decisions based on my feelings); (e) Relational/Divergent with 8 items (e.g., To make a decision, I like getting different points of view). The alpha internal consistency coefficient for the five factors ranged from 0.52 to 0.97 .

Pedagogical Practices that Promote Creativity: The Inventory of Teaching Practices for Creativity in Higher Education (Alencar \& Fleith, 2004b) was administered to assess the participants' perception about the extent to which their college professors have used pedagogical practices that promote the expression of students' creativity. It consists of 37 items answered on a 5-point scale, ranging from (1) strongly disagree to (5) strongly agree. The validation study of the instrument indicated that it evaluates the following factors: (a) Incentive to New Ideas, with 14 items regarding the stimulation of cognitive abilities and affective characteristics associated with students' creativity; (b) Climate Atmosphere for the Expression of Ideas, which includes 6 items related specially to the professor's attitude of respect and acceptance of students' ideas; (c) Evaluation and Teaching Methodology, which includes 5 items regarding teaching practices conducive to the development of creative expression; (d) Interest in Students' Learning, with 12 items related to teaching strategies and resources that motivate students to learn in a creative way. Alpha internal consistency coefficient for the different factors ranged from 0.72 to 0.93 . The following are examples of the inventory items: Typical behaviors of my professors in the classroom are: cultivates in students interest concerning new discoveries and new knowledge; creates an environment of respect and acceptance of students' ideas; and uses examples to illustrate what is being discussed in class.

\section{Procedures}

At first the deans and professors of the Pedagogy and the Teachers' Certificate in Mathematics courses from a public and private university were contacted with the purpose of (a) presenting the project; (b) requesting permission for students to answer the instruments and (c) scheduling time for the application of the scales and inventory in the classroom. Data collection was performed by the first author. In most applications, the author was accompanied by a university student, who helped with the distribution and collection of the questionnaire. The ethical guidelines ensuring confidentiality and the option to participate or not in the survey were respected. All students signed an informed term of consent form. Analyses of variance and Pearson correlations were used in the study.

\section{Results}

Significant differences were observed between students from public $(M=3.25, S D=0.37)$ and private universities $(M=3.37, S D=0.36)$ regarding intrinsic motivation, favoring the latter ones $F(1,355)=5.70, p=0.017$. On the other hand, students from public universities $(M=1.98, S D=0.44)$ 
obtained a significantly higher mean with respect to extrinsic motivation than those from the private university $(M=1.82, S D=0.41 ; F[1.355]=6.98$, $p=0.009$ ). No statistically significant differences were observed regarding the motivational orientation considering gender and course (Table 1). The results revealed that motivational orientation was predominantly intrinsic for all students, irrespective of gender, course or university.

In respect to the factors of the Scale of Thinking and Creative Styles, significant differences between genders were found in the Cautious/ Reflective style, $F(1,355)=14.619 ; p=0.0001$, having the female students $(M=88.01, S D=8.09)$, compared to male students $(M=83.14, S D=11.25)$, obtained a higher mean. Higher mean was also obtained by private university students $(M=93.98$, $S D=18.26)$ in comparison with those from the public university $(M=88.79, S D=17.39)$ in the Nonconformist/Transformer style, $F(1,355)=9.557$, $p=0.002$. Furthermore, Mathematics undergraduates scored significantly higher $(M=112.85, S D=8.76)$ than Pedagogy undergraduates $(M=108.14$, $S D=10.93)$ in the Logical/Objective style, $F(1.355)$ $8.27, p=0.004$. When comparing women and men in this style, an expressive difference was observed in favor of male students, although this difference did not reach a statistical significance, $F(1,355)=3.746$; $p=0.054$. No significant differences were found between the groups regarding the Emotional/ Intuitive and Relational/Divergent styles (Table 2).

First order interactions were observed between gender and course in the Nonconformist/
Transformer and Logical/Objective styles. The differences between means in the Nonconformist/ Transformer style occurred only among Teachers' Certificate in Mathematics undergraduates in which a higher mean was obtained by female students $(M=95.42)$ in comparison with male students $(M=88.28 ; F[1,354]=4.296, p=0.039)$. As for the Logical/Objective style, the male Mathematics undergraduates' mean $(M=115.35)$ was higher than the mean presented by female undergraduates $(M=108.58), F[1,354]=6.758, p=0.010) . A$ second order interaction was also found between gender, course and university in the Nonconformist/ Transformer style, $F(1.354)=4.992, p=0.026)$. The data revealed a significantly higher mean $(M=105.67)$ by male Pedagogy undergraduates from the private university when compared to other students of the course. On the other hand, with regard to Mathematics, female Mathematics undergraduates from the private university obtained a higher mean $(M=99.15)$ than other students of the same course.

As shown in Table 3, no significant differences between genders were found in the factors of the Inventory of Teaching Practices for Creativity in Higher Education. However, students from the private university scored higher than those from the public university in all scale factors. The Pedagogy undergraduates obtained higher scores than Teachers' Certificate in Mathematics undergraduates in Factors 1 (Incentive to New Ideas) and 3 (Evaluation and Teaching Methodology). Interactions between university and course were noticed for Factors $1, F(1,354)=8.90, p=0.0001$,

Table 1

Mean, Standard Deviation, F Value, and $p$ in intrinsic and extrinsic motivation orientations of pedagogy and teachers' certificate in mathematics, male and female students, from public and private university

\begin{tabular}{|c|c|c|c|c|c|c|c|c|}
\hline \multirow{2}{*}{ Variables } & \multicolumn{4}{|c|}{ Intrinsic Motivation } & \multicolumn{4}{|c|}{ Extrinsic Motivation } \\
\hline & M & $S D$ & $F$ & $p$ & M & $S D$ & $F$ & $p$ \\
\hline Pedagogy & 3.32 & 0.37 & 0.20 & n.s. & 1.90 & 0.43 & 0.41 & n.s. \\
\hline Mathematics & 3.30 & 0.38 & & & 1.90 & 0.44 & & \\
\hline Male students & 3.24 & 0.42 & 3.188 & n.s. & 1.89 & 0.45 & 1.063 & n.s. \\
\hline Female students & 3.35 & 0.34 & & & 1.91 & 0.43 & & \\
\hline Public University & 3.25 & 0.37 & 5.70 & 0.017 & 1.98 & 0.44 & 6.98 & 0.009 \\
\hline Private University & 3.37 & 0.36 & & & 1.82 & 0.41 & & \\
\hline
\end{tabular}


Table 2

Mean, Standard Deviation, F Value, and $p$ in the Factors of the Scale for Thinking and Creative Styles in which differences were found university

\begin{tabular}{|c|c|c|c|c|}
\hline Styles & Mean & Standard Deviation & $F$ & $p$ \\
\hline \multicolumn{5}{|l|}{ Cautious/Reflective } \\
\hline Male students & 83.14 & 8.09 & 14.619 & 0.0001 \\
\hline Female students & 88.01 & 11.25 & & \\
\hline \multicolumn{5}{|c|}{ Nonconformist/Transformer } \\
\hline Public University & 88.79 & 17.39 & 9.557 & 0.002 \\
\hline Private University & 93.98 & 18.26 & & \\
\hline \multicolumn{5}{|l|}{ Logic/Objective } \\
\hline Pedagogy & 108.14 & 10.93 & 8.27 & 0.004 \\
\hline Mathematics & 112.85 & 8.76 & & \\
\hline Male students & 113.83 & 9.46 & 3.746 & 0.054 \\
\hline Female students & 108.32 & 10.21 & & \\
\hline
\end{tabular}

Table 3

Mean, Standard Deviation, F Value, and $p$ in the factors of the Inventary of Teaching Practices for Creativity in Higher Education of male and female students, from Pedagogy and Teachers' Certificate in Mathematics, Public and Private University

\begin{tabular}{|c|c|c|c|c|c|c|}
\hline \multirow{3}{*}{ Factors } & \multicolumn{4}{|c|}{ Variables } & \multirow{3}{*}{$F$} & \multirow{3}{*}{$p$} \\
\hline & \multicolumn{2}{|c|}{ Male } & \multicolumn{2}{|c|}{ Female } & & \\
\hline & $M$ & $D P$ & $M$ & $D P$ & & \\
\hline Factor 1 & 3.52 & 0.57 & 3.67 & 0.64 & 0.022 & n.s. \\
\hline Factor 2 & 3.66 & 0.63 & 3.60 & 0.70 & 1.352 & n.s. \\
\hline Factor 3 & 2.84 & 0.81 & 3.18 & 0.79 & 0.058 & n.s. \\
\hline \multirow[t]{2}{*}{ Factor 4} & 3.68 & 0.50 & 3.62 & 0.62 & 1.334 & n.s. \\
\hline & \multicolumn{2}{|c|}{ Pedagogy } & \multicolumn{2}{|c|}{ Mathematics } & & \\
\hline Factor 1 & 3.68 & 0.62 & 3.53 & 0.60 & 5.720 & 0.017 \\
\hline Factor 2 & 3.58 & 0.69 & 3.67 & 0.65 & 0.003 & n.s. \\
\hline Factor 3 & 3.23 & 0.79 & 2.84 & 0.80 & 14.640 & 0.0001 \\
\hline \multirow[t]{2}{*}{ Factor 4} & 3.60 & 0.61 & 3.70 & 0.55 & 0.006 & n.s. \\
\hline & \multicolumn{2}{|c|}{ Public University } & \multicolumn{2}{|c|}{ Private University } & & \\
\hline Factor 1 & 3.45 & 0.52 & 3.80 & 0.67 & 21.37 & 0.0001 \\
\hline Factor 2 & 3.40 & 0.61 & 3.87 & 0.65 & 29.61 & 0.0001 \\
\hline Factor 3 & 2.88 & 0.79 & 3.26 & 0.80 & 17.70 & 0.0001 \\
\hline Factor 4 & 3.49 & 0.51 & 3.80 & 0.61 & 19.93 & 0.0001 \\
\hline
\end{tabular}

Note: $p<0.01$. n.s.: not significant; $M$ : Mean; SD: Standard Deviation.

and $4, F(1,354)=8.06, p=0.005$, respectively. In these factors, the means of Pedagogy undergraduates from the private university $(M=3.97, S D=0.58$ and $M=3.84, S D=0.64$ ) were significantly higher than those of Mathematics undergraduates $(M=3.60$, $S D=0.71$ and $M=3.76, S D=0.58$ ) of the same university. On the other hand, Teachers' Certificate in Mathematics undergraduates from the public university scored significantly higher $(M=3.45$,

508 $S D=0.47$ and $M=3.61, S D=0.50$ ) than Pedagogy undergraduates $(M=3.44, S D=0.55$ and $M=3.40$, $S D=0.50)$ of the same university in Factors 1 and 4.

The results also showed a significant, although weak, positive correlation $(p<0.01)$ ranging from 0.17 to 0.28 between intrinsic motivation and the four factors of the Inventory of Teaching Practices for Creativity on Higher Education, indicating that the higher the students' intrinsic motivation, the more positive their perception of professors' 
teaching practices for creativity. Significant negative correlations $(p<0.01)$, though low, ranging from 0.16 to -0.19 , were found between the two variables investigated (extrinsic motivational orientation and pedagogical practices that promote creativity). Although significant, the correlations were generally weak, possibly due to the large sample size. The relationship between students' cognitive styles and their perception of professors' pedagogical practices that promote creativity were also investigated. It was found a significant positive correlation $(p<0.01)$ between the Nonconformist/ Transformer style and all factors of the Inventory of Teaching Practices for Creativity in Higher Education (correlation coefficient ranging from 0.20 to 0.31 ); the Relational/Divergent cognitive style was positively related to Factor 1 (Incentive to New Ideas, $r=0.19$ ), Factor 2 (Climate for Expression of Ideas, $r=0.18$ ) and Factor 4 (Interest in Student Learning, $r=0.23)$, but correlations were weak. The Cautious/ Reflective style was negatively related $(p<0.05)$ to Factors $1(r=-0.11), 3(r=-0.13)$ and $4(r=-0.16)$ of the Inventory of Teaching Practices for Creativity in Higher Education. Positive correlations with higher values were obtained between intrinsic motivational orientation, Nonconformist/ Transformer $(r=0.481 ; p<0.01)$, and Relational/ Divergent styles $(r=0.326 ; p<0.01)$. Moreover, a significant negative correlation was found between intrinsic motivation and the Cautious/Reflective style $(r=-0.265 ; p<0.01)$, while a positive correlation was observed between this style and extrinsic motivation $(r=0.368 ; p<0.01)$. A significant negative correlation, although low, was also found between Logical/Objective style and Extrinsic Motivation $(r=0.198 ; p<0.01)$. The results suggest that the higher intrinsic motivational orientation, the more probable the student to be distinguished in the Nonconformist/Transformer and Relational/ Divergent styles (Table 4).

\section{Discussion}

The present study examined differences between students' gender (male and female), course (Pedagogy and Teachers' Certificate in Mathematics) and university (public and private) regarding their motivational orientations, cognitive styles and perception of professors' teaching practices that promote creativity. With regard to motivational orientations, the results indicated that students from the private university showed a prevalence of intrinsic motivation while extrinsic motivation prevailed in the public university. These results suggest that students from the private university who participated in the study presented a more appropriate motivational orientation concerning better quality learning than those from the public university. Several authors, such as Boruchovitch (2008b), Guimarães, Bzuneck, and Sanches (2002), and Zenorine and Santos (2004), draw attention to the association between intrinsic motivation, better academic performance, greater engagement in activities that provide opportunities for improving abilities, and higher retention of the learned content. Other authors highlight an association between intrinsic motivation, positive

Table 4

Pearson Correlations among Fators of the Inventary of Teaching Practices for Creativity in Higher Education, Intrinsic Motivation and Cognitive Styles

\begin{tabular}{lccccccc}
\hline Factors & $\begin{array}{c}\text { Cautious } \\
\text { Reflective }\end{array}$ & $\begin{array}{c}\text { Inconformist } \\
\text { Transformer }\end{array}$ & $\begin{array}{c}\text { Logic } \\
\text { Objective }\end{array}$ & $\begin{array}{c}\text { Emotional } \\
\text { Intuitive }\end{array}$ & $\begin{array}{c}\text { Relational } \\
\text { Divergent }\end{array}$ & $\begin{array}{c}\text { Intrinsic } \\
\text { Motivation }\end{array}$ & $\begin{array}{c}\text { Extrinsic } \\
\text { Motivation }\end{array}$ \\
\hline Factor 1 & $-0.112^{*}$ & $0.267^{* *}$ & 0.041 & $-0.112^{*}$ & $0.193^{* *}$ & $0.280^{* *}$ & $-0.190^{* *}$ \\
Factor 2 & 0.097 & $0.209^{* *}$ & 0.097 & 0.086 & $0.180^{* *}$ & $0.172^{* *}$ & $-0.159^{* *}$ \\
Factor 3 & $-0.133^{* *}$ & $0.195^{* *}$ & -0.084 & -0.039 & 0.087 & $0.202^{* *}$ & $-0.175^{* *}$ \\
Factor 4 & $-0.161^{* *}$ & $0.312^{* *}$ & $0.117^{*}$ & 0.096 & $0.228^{* *}$ & $0.254^{* *}$ & $-0.184^{* *}$ \\
Intrinsic motivation & $-0.265^{* *}$ & $0.481^{* *}$ & -0.064 & $0.182^{* *}$ & $0.326^{* *}$ & & \\
Extrinsic motivation & $0.368^{* *}$ & $-0.310^{* *}$ & $0.198^{* *}$ & 0.06 & $-0.186^{* *}$ & & \\
\hline
\end{tabular}

Note: ${ }^{*} p<0.05 ;{ }^{* *} p<0,01$. 
emotional states and creativity (Alencar \& Galvão, 2007; Amabile \& Mueller, 2008; Cropley, 2005; Csikszentmihalyi, 1990). It has also been noted that intrinsic motivation is often accompanied or preceded by extrinsic motivation, which seems to yield good results (Boruchovitch, 2008b; Costa \& Boruchovitch, 2010). Along this line, Barker (2002) points out that students have a variety of learning motivations and that the effectiveness and efficiency of the act of learning depend on both intrinsic and extrinsic motivation, among other factors. The same is true with respect to creativity, according to several authors, such as Lubart and Sternberg (1995) and Lubart (2007), for whom both types of motivationintrinsic and extrinsic-often interact with each other to strengthen creativity.

Regarding the variable type of university, our findings partially differ from those obtained by Boruchovitch (2008b), who found significantly higher means in both types of motivation in a sample of public university students. It is possible that the students from Brazilian private universities, many of them being both students and workers who pay for their studies, value more the opportunity of studying and getting a college degree, thus devoting themselves to schoolwork. On the other hand, with respect to gender, unlike what was observed in the present research, Boruchovitch (2008b), Guimaraes et al. (2002), Sobral (2003), and Zenorine and Santos (2004) found significantly higher means for female students in both types of motivation. Possibly contextual variables, not investigated in this study, could help explain this discrepancy.

Concerning cognitive styles, it was found that private university students scored significantly higher in the Nonconformist/Transformer style than public university students; female undergraduates had better performance in the Reflective/Cautious style in comparison with the male undergraduates, while this latter group scored significantly higher in the Logical/Objective style comparing to female students. Many of the items included in the Nonconformist/Transformer style, as the name suggests, are more directly related to characteristics of individuals with higher level of creativity (Alencar
\& Fleith, 2009; Cropley, 2005; Martínez, 2002; Nakano \& Wechsler, 2007; Treffinger et al., 2013). This finding suggests a possible difference between private and public university participants, favoring the former ones, in the profile regarding creativity. This is an aspect that deserves to be included in the agenda of future studies, particularly because it is a relatively new theme discussed by scholars interested in creativity. The differences between genders observed in this study are in agreement with the literature regarding the influence of culture on the development of the identity of gender role. From an early age, individuals receive signals of what is expected from them. It is expected, for example, that men be more objective, run more risks, have greater initiative and be more independent; whereas women are expected to be more cautious, reflective, conformist and better students (Alencar \& Fleith, 2009; Esquivel \& Hodes, 2003).

With regard to the participants' perception of professors' teaching practices, it was found that private university and Pedagogy students rated their professors as those who promote better conditions for the expression of creativity when compared to those from the public university and Teachers' Certificate in Mathematics course. This more positive assessment occurred in all the factors of the Inventory of Teaching Practices for Creativity in Higher Education by students from the private university, and in the factors Incentive to New Ideas and Evaluation and Teaching Methodology by the Pedagogy students. Similarly to findings of Alencar (1997, 2002), who conducted investigations with undergraduate and graduate students, no differences between genders were found in this study. The differences identified between Pedagogy and Teachers' Certificate in Mathematics students can possibly be attributed to the professors' training of the former course and the nature of the disciplines in the curriculum in which topics related to a variety of teaching methodologies and of learning assessment are much more frequent.

The more positive assessment of teaching practices by private university students in comparison with those from the public university, which was also observed by Ribeiro and Fleith (2007), is difficult to explain, especially because the data were 
collected in one of the top-rated public universities in Brazil, known by its highly qualified teaching staff - although has precarious infrastructure and limited teaching resources available to professors. One hypothesis to explain the more positive assessment by the private university students could be the professors' attitude in promoting a more appropriate environment for the expression of students' ideas, besides the implementation of a diversification of methods and strategies to maintain students' interest, a condition that contributes to the positive students' evaluation of professors from private universities, who are striving for a tenured position. This seems to be a topic that deserves attention in further studies.

A significant positive association was observed between intrinsic motivation and perception of teaching practices that promote creativity and a significant negative relationship between extrinsic motivational orientation and perception of teaching practices that promote creativity. These results indicate that the more students are intrinsically motivated, the more positive their perception of the professors' incentive to creativity. These findings are in agreement with those of Otaviano et al. (2012), who conducted a study with high school students. Similarly, these researchers found a significant relationship between the perception of the Mathematics teacher's instructional practices that promote creativity and motivation in this discipline. Fleith (2014) also found significant positive correlations between motivation to learn and perception of classroom climate for creativity among $5^{\text {th }}$ grade gifted and non-gifted students. It is noteworthy that, in the literature on creativity, the role of motivation in creative production, particularly intrinsic motivation, is widely documented (Alencar \& Fleith, 2009; Amabile, 1996; Amabile \& Mueller, 2008). These and other authors highlight that higher levels of intrinsic motivation have a positive impact on creative expression, besides having practical advantages for learning in comparison to extrinsic motivation (Costa \& Boruchovitch, 2010).

One of the interesting findings was the significant positive relationships between the Nonconformist/Transformer style and all the factors of the Inventory of Teaching Practices for Creativity in Higher Education. The items of the Nonconformist/
Transformer factor are related to characteristics of people who stand out for their creativity. This result suggests that college students with a creative profile who participated in this study tend to perceive their professors as those who provide greater incentive for creative expression. The significant positive association between Divergent/Relational Cognitive style and the factors Climate for Expression of Ideas and Interest in Student Learning was also interesting. However, the correlations between these two variables, although highly significant, were weak, and further studies must be conducted to investigate these relationships. The significant, moderately high positive association between the Nonconformist/ Transformer style and intrinsic motivation and negative correlation of this style with extrinsic motivation called our attention. This result leads us to assume that individuals who stand out for having this style have advantages in their learning process, since their motivational orientation of more intrinsic nature is associated with feelings of pleasure, satisfaction, interest, curiosity in the act of studying and learning, with a consequent positive impact on their school performance. Further studies should investigate the nature of these relationships. Although the present study has limitations, for example, data collected from students from only one private and one public university, and from only two courses, the results have contributed to advance knowledge on the different variables examined. It also highlights the importance of using other qualitative methods such as behavioral observation.

\section{Contributors}

E. M. L. S. ALENCAR was responsible for the research design, the data collection and analyses, the discussion of the results, and the manuscript writing. D. S. FLEITH was responsible for the data analyses, the discussion of the results, and the manuscript writing.

\section{References}

Alencar, E. M. L. S. (1997). O estímulo à criatividade no contexto universitário. Psicologia Escolar e Educa- 
cional, 1(1), 29-37. http://dx.doi.org/10.1590/S1413-8 5571997000100004

Alencar, E. M. L. S. (2002). O estímulo à criatividade em programas de pós-graduação segundo seus estudantes. Psicologia: Reflexão e Crítica, 15(1), 63-69. http://dx.doi.org/10.1590/S0102-79722002000 100008

Alencar, E. M. L. S., \& Fleith, D. S. (2004a). Creativity in university courses: Perceptions of professors and students. Gifted and Talented International, 19(1), 24-28.

Alencar, E. M. L. S., \& Fleith, D. S. (2004b). Inventário de práticas docentes que favorecem a criatividade no ensino superior. Psicologia: Reflexão e Crítica, 17(1), 105-110. http://dx.doi.org/10.1590/S0102-7972200 4000100013

Alencar, E. M. L. S., \& Fleith, D. S. (2009). Criatividade. Múltiplas perspectivas. Brasília: UnB.

Alencar, E. M. L. S., \& Galvão, A. (2007). Condições favoráveis à criação nas ciências e nas artes. In A. M. R. Virgolim (Ed.), Talento criativo: expressão em múltiplos contextos (pp.103-19). Brasília: UnB.

Amabile, T. M. (1996). Creativity in context. Boulder: Westview Press.

Amabile, T. M., \& Mueller, J. S. (2008). Studying creativity, its processes, and its antecedents: An exploration of the componential theory of creativity. In J. Zhou \& C. E. Shalley (Eds.), Handbook of organizational creativity (pp.33-64). New York: Lawrence Erlbaum.

Amaral, A. L. N., \& Martínez, A. M. (2009). Aprendizagem criativa no ensino superior: a significação da dimensão subjetiva. In A. M. Martínez \& M. C. V. R. Tacca (Eds.), A complexidade da aprendizagem. Destaque ao ensino superior (pp.149-192). Campinas: Alínea.

Barker, P. (2002). Interactivity as an extrinsic motivating force in learning. In S. Brown, S. Armstrong, \& G. Thompson (Eds.), Motivating students (pp.15-23). London: Routledge.

Boruchovitch, E. (2008a). Escala de Motivação para Aprender de Universitários (EMA-U): propriedades psicométricas. Avaliação Psicológica, 7(2), 127-134.

Boruchovitch, E. (2008b). A motivação para aprender de estudantes em cursos de formação de professores. Educação, 31(1), 30-38.

Costa, E. R., \& Boruchovitch, E. (2010). Motivação e escrita. Algumas contribuições para a prática pedagógica. In E. Boruchovitch, J. A. Bzuneck, \& S. E. R. Guimarães (Eds.), Motivação para aprender: aplicações no contexto educativo (pp.193-208). Petrópolis: Vozes.

Cropley, A. J. (2005). Creativity in education and learning. London: Routledge.

Csikszentmihalyi, C. (2006). Developing creativity. In N. Jackson, M. Oliver, M. Shaw, \& J. Wisdom (Eds.), Developing creativity in higher education (pp. XVIII-XX).

512 London: Routledge.
Csikszentmihalyi, M. (1990). Flow: The psychology of optimal experience. New York: Harper \& Row.

Csikszentmihalyi, M. (1994). The domain of creativity. In D. H. Feldman, M. Csikszentmihalyi, \& H. Gardner (Eds.), Changing the world. A framework for the study of creativity (pp.135-58). Westport: Praeger.

Csikszentmihalyi, M. (1999). Implications of a systems perspective for the study of creativity. In R. J. Sternberg (Ed.), Handbook of creativity (pp.313-335). New York: Cambridge University Press.

Esquivel, G. B., \&Hodes, T. G. (2003). Creativity, development, and personality. In J. Houtz (Ed.), The educational psychology of creativity (pp.135-166). Cresskill: Hampton Press.

Feist, G. J. (2010). The function of personality in creativity: The nature and nurture of the creative personality. In J. C. Kaufman \& R. J. Sternberg (Eds.), The Cambridge handbook of creativity (pp.113-130). New York: Cambridge University Press.

Fleith, D. S. (2014). Clima de sala de aula para criatividade, motivação para aprender e ambiente familiar: um estudo comparativo entre alunos superdotados e alunos não superdotados [Relatório de pesquisa]. Brasília: Conselho Nacional de Desenvolvimento Científico e Tecnológico.

Fleith, D. S., \& Alencar, E. M. L. S. (2010). A inter-relação entre criatividade e motivação. In E. Boruchovitch, A. Bzuneck, \& S. E. R. Guimarães (Eds.), Motivação para aprender (pp.209-230). Petrópolis: Vozes.

Guimarães, S. E., Bzuneck, J. A., \& Sanches, S. F. (2002). Psicologia educacional nos cursos de licenciatura: a motivação dos estudantes. Psicologia Escolar e Educacional, 6(1), 11-19. http://dx.doi.org/10.1590/ S1413-85572002000100002

Hosseini, A. (2011). University student's evaluation of creative education in universities and their impact on their learning. Procedia Social and Behavioural Sciences, 15, 1806-1812. http://dx.doi.org/10.1016/j.sbspro. 2011.04.007

Jackson, N., Oliver, M., Shaw, M., \& Wisdom, J. (Eds.). (2006). Developing creativity in higher education. New York: Routledge.

Kirschenbaum, R. J., \& Armstrong, D. C. (1999). Diagnostic assessment of creativity in students. In A. S. Fishkin, B. Cramond, \& P. Olszewski-Kubilius (Eds.), Investigating creativity in youth (pp.329-348). Creskill: Hampton Press.

Lemons, G. (2005). When the horse drinks: Enhancing everyday creativity using elements of improvisation. Creativity Research Journal, 17(1), 25-36. http://dx. doi.org/10.1207/s15326934crj1701_3

Lubart, T. (2007). Psicologia da criatividade. Porto Alegre: ArtMed.

Lubart, T., \& Sternberg, R. J. (1995). An investment approach to creativity: Theory and data. In S. M. Smith, 
T. B. Ward, \& R. A. Fink (Eds.), The creative cognition approach (pp.271-302). Cambridge: MIT Press.

Martínez, A. M. (2002). Criatividade, personalidade e educação ( $3^{a}$ ed.). Campinas: Papirus.

McCluskey, K. W. (2013). Thoughts about tone, educational leadership, and building creative climates in our schools (2 ${ }^{\text {nd }}$ ed.). UIm: ICIE.

Morgan, S., \& Foster, J. (1999). Creativity in the classroom. Gifted Education International, 14(1), 29-43.

Nakano, T. C. (2010). Estilos de pensar e criar em estudantes de psicologia: diferenças regionais. Estudos e Pesquisas em Psicologia, 10(3), 682-699.

Nakano, T. C., Santos, E., Zavariz, S. F., \& Wechsler, S. M. (2010). Estilos de pensar e criar em universitários das áreas de humanas e sociais aplicadas: diferenças por gênero e curso. Psicologia: Teoria e Prática, 12(3), 120-134.

Nakano, T. C., \& Siqueira, L. G. G. (2011). Avaliação dos estilos de pensar e criar em universitários. In S. M. Wechsler \& T. C. Nakano (Eds.), Criatividade no ensino superior: uma perspectiva internacional (pp.236-263). São Paulo: Vetor.

Nakano, T. C., \& Wechsler, S. M. (2007). Identificação e avaliação do talento criativo. In D. S. Fleith \& E. M. L. S. Alencar (Eds.), Desenvolvimento de talentos e altas habilidades (pp.87-98). Porto Alegre: ArtMed.

Niu, W. (2007). Individual and environmental influences on Chinese student creativity. The Journal of Creative Behavior, 41(3), 151-175. http://dx.doi.org/10.1002/j. 2162-6057.2007.tb01286.x

Otaviano, A. B. N., Alencar, E. M. L. S., \& Fukuda, C. (2012). Estímulo à criatividade por professores de Matemática e motivação do aluno. Psicologia Escolar e Educacional, 16(1), 61-69. http://dx.doi.org/10.1590/S 1413-85572012000100007

Phelan, S., \& Young, A. M. (2003). Understanding creativity in the workplace: An examination of individual styles and training in relation to creative confidence and creative self-leadership. The Journal of Creative Behavior, 37(4), 266-281. http://dx.doi.org/10.1002/j. 2162-6057.2003.tb00994.x

Renzulli, J. S. (2005). Neglecting creativity. Education Week, 24, 31-32 and 40.

Ribeiro, R. A., \& Fleith, D. S. (2007). O estímulo à criatividade em cursos de licenciatura. Paidéia, 17(38), 413-416. http://dx.doi.org/10.1590/S0103-863X200700 0300010
Rubenstein, V., McCoach, D. B., \& Siegle, D. (2013). Teaching for creativity scale: An instrument for examine teachers' perceptions of factors that allow for the teaching of creativity. Creativity Research Journal, 25(3), 324-334. http://dx.doi.org/10.1080/10400419. 2013.813807

Sobral, D. T. (2003). Motivação do aprendiz de medicina: uso da escala de motivação acadêmica. Psicologia: Teoria e Pesquisa, 19(1), 25-31. http://dx.doi.org/10. 1590/S0102-37722003000100005

Sternberg, R. J. (2006). The nature of creativity. Creativity Research Journal, 18(1), 87-98. http://dx.doi.org/ 10.1207/s15326934crj1801_10

Sternberg, R. J. (2012). The assessment of creativity: An investment-based approach. Creativity Research Journal, 24(1), 3-12. http://dx.doi.org/10.1080/104 00419.2012 .652925

Sternberg, R. J., \& Lubart, T. I. (1995). Defying the crowd. Cultivating creativity in a culture of conformity. New York: The Free Press.

Treffinger, D. J. (2003). Assessment and measurement in creativity and creative problem solving. In J. Houtz (Ed.), The educational psychology of creativity (pp.59-94). Creskill: Hampton Press.

Treffinger, D. J., Schoonover, P. F., \& Selby, E. C. (2013). Educating for creativity \& innovation. Waco: Prufrock Press.

Wechsler, S. M. (1998). Pensando criativamente na universidade. Psicologia Escolar e Educacional, 2(1), 67-72. http://dx.doi.org/10.1590/S1413-855719980001 00009

Wechsler, S. M. (2002). Criatividade e desempenho escolar: uma síntese necessária. Linhas Críticas, 8(15), 179-188.

Wechsler, S. M. (2006). Estilos de pensar e criar. Campinas: Lamp/Puc.

Wechsler, S. M., \& Nakano, T. C. (Eds.). (2011). Criatividade no ensino superior: uma perspectiva internacional. São Paulo: Vetor.

Zenorine, R. P. C., \& Santos, A. A. A. (2004). A motivação e a utilização de estratégias de aprendizagem em universitários. In E. Mercuri \& A. J. Polydoro (Eds.), Estudantes universitários: características e experiências de formação (pp.67-86). Taubaté: Cabral e Livraria Universitária.

Received: March 25, 2014

Final version: November 25, 2014

Approved: January 8, 2015 
